Lybia) and 134 mixed population. The method used was vertical starch-gel electrophoresis as described by Smithies". The starch was sliced longitudinally into two parts; one was stained with benzidine, the other with brom-phenol blue or amido-black $10 \mathrm{~B}$. To the sera 120-150 mgm. per cent of oxyhrmoglobin was added to saturate the haptoglobins completely. The results are presented in Table 1.

Table 1. HAPTOGLOBIN TYPES AND FREQUENCY of ALILELE $H p^{1}$ AMONG DIFFERENT ETHNIC GROUPS IN ISRAEL ATHEL

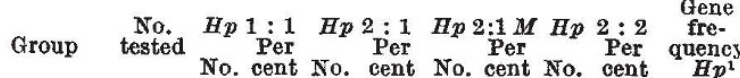

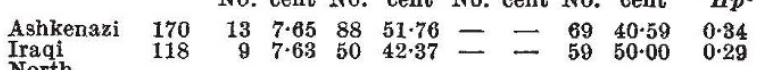

$$
\begin{aligned}
& \begin{array}{lllllllllll}
\text { African } & 104 & 8 & 7 \cdot 69 & 43 & 41.35 & 1 & 0.96 & 52 & 50.00 & 0.29
\end{array} \\
& \text { Rest of }
\end{aligned}
$$

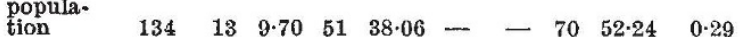

No cases of ahaptoglobinæmia were found except in hæmolytic anæmias, which are not included in this work. Only one case of $2: 1 M$ was found, that being among the North African Jews. The gene frequency of $H_{p}^{1}$ in Ashkenazi Jews was found to be 0.34, while that found among the Iraqi and the North African Jews was $0 \cdot 29$. 'This difference is not statistically significant. The expected values of phenotype were calculated on the basis of the Hardy-Weinberg equilibrium and were found to correspond closely to the observed numbers.

Our results show that the frequency of $H p^{1}$ among the Ashkenazi Jews is similar to that found in European populations ${ }^{2}$, while the Iraqi and North African Jews have a lower frequency of $H p^{1}$ similar to that found in Asian populations ${ }^{8}$. Other Jewish and Arab populations are under investigation.

This work was supported by Rockefeller Foundation grant $R E$ : GA BMR 5936. We thank Dr. Eloise Giblett for her valuable suggestions.

$$
\begin{aligned}
& \text { Bracha Ramot } \\
& \text { Poriya Zikert-Duvdevant } \\
& \text { Gismia Tauman }
\end{aligned}
$$

Tel-Hashomer Government Hospital, Israel.

${ }^{2}$ Smithies, O., Biochem. J., 61, 629 (1955).

${ }^{2}$ Allison, A. C., Blumberg, B. S., and ap Rees, Nature, 181, 824 (1958). Moullec, J., and Fine, J. A., ibid., 184, 196 (1959). Baitsch, H., $976(1960)$. Harris, H., Robson, E. B., and Siniscalco, M., Ciba Symp. on Medical Biology and Etruscan Origins, 220 (1959).

${ }^{a}$ Kirk, R. L., Lai, L. Y. C., Mahmood, S., and Bhagwan Singh, R. Niture, 185,185 (1960). Matsunaga, E,, and Kyokn Murai, ibid.', $186,320(1960)$.

1 Mourant, A. E., The ABO Blood Groups; Comprehensive Tables and Maps of World Distribution, 12 (Blackwell Sclentific Pub., Oxford, 1958).

s Szelnberg, A., Sheba, Oh., and Adam, A., Blood, 13, 1043 (1958).

"Smithies, O., Biochem. J., 71, 585 (1959).

\section{Distribution of Group-specific Components (Gc) in the Sera of Native Africans}

THE group-specific components of sera consist of electrophoretically variable $\alpha_{2}$-globulins demonstrable by means of an immuno-electrophoretic technique ${ }^{1}$. This system allows a division of human sera into three qualitatively different patterns characterized by the presence of a fast-moving group-specific component $(G c 1-1)$, a slow-moving component ( $G c 2-2)$, which in immuno-electrophoresis both give normally arc-shaped precipitates, or the simultaneous presence of both fast- and slow-moving components (Gc 2-1), which in immuno-electrophoresis give an extended two-peaked precipitate due to a reaction of immuno- logical identity between these electrophoretically different although immunologically identical fastand slow-moving components ${ }^{1}$. Investigations on sera from 42 families with 137 children and more than 600 mother-child combinations have shown that these serum patterns are genetically determined by two autosomal alleles $\left(G c^{1}\right.$ and $\left.G c^{2}\right)$ without dominance where the serum types Gc 1-1 and Gc 2-2 are the homozygotes and $G c$ 2-1 the heterozygote. Up to now, no exceptions to this genetical theory or unresolved typing difficulties has been found in the material investigated ${ }^{2,3}$.

Table 1. Frequencies of the $G c^{1}$-Gene in Vartods Populations Population No.tested $G c^{1} \quad G c$-determinations carried $\begin{array}{lrll}\text { Sweden } & 1,744 & 0.74 & \text { Hirschfeld } \\ \text { Swedish Lapps } & 79 & 0.87 & \text { Hirschfeld * } \\ \text { New York Whites } & 86 & 0.74 & \text { Bearn and Cleve } \\ \text { New York Negroes } & 120 & 0.90 & \text { Bearn and Cleve } \\ \text { Navajo Indians } & 197 & 0.98 & \text { Bearn and Cleve } \dagger\end{array}$ * Hirschfeld, J., and Beckman, L., Acta Genet., 11, 185 (1961). + Personal communication.

Table 2. DIsTRIBUtion OF Ge-TYPES IN SERA FROM 100 ARRICANS

$$
\begin{array}{ccccc} 
& G c 1-1 & G c 2-1 & G c 2-2 & G c c^{1} \\
\text { obs. } & 82 & 17.9 & 1 & 0.91 \\
\text { exp. } & 81.9 & 17 \cdot 2 & 0.9 &
\end{array}
$$

The frequencies of the $G c^{1}$-gene in populations hitherto investigated are given in Table 1. In Table 2, the distribution of $G c$ in a serum sample consisting of sera from 100 native Africans collected in Léopoldville, Congo, are given. The results seem to show that the system might be of value in connexion with anthropological investigations, and further work concerning the distribution of $G c$-types in different populations is in progress.

One of us (J.H.) gratefully acknowledges a grant from Lennanders Fond, Uppsala, Sweden.

Note added in proof. A more detailed survey of the distribution and inheritence of the $G c$-system will be given elsewhere ${ }^{3}$.

JAN HIRSChFELD

State Institute for Blood Group Serology,

Statens Rättskemiska Laboratorium, Stockholm 60 .

JEAN SONNET

Cliniques Universitaires Université Lovanium, Léopoldville, Congo.

' Hirschfeld, J., Acta Path. Microbiol. Scand., 47, 160 (1959); Science Tools, 7, $18(1960)$

2 Hirschfeld, J., Jonsson, B., and Rasmuson, M., Nature, 185, 931 (1960).

- Hirschfeld, J., Progress in Allergy (in the press).

\section{RADIOBIOLOGY}

\section{Autoradiographic Study of Cell Migration during Histogenesis of Cerebral Cortex in the Mouse}

Autoradiography with thymidine labelled with tritium has proved useful for the study of histogenesis in the mammalian brain ${ }^{1-8}$. Labelled thymid. ine injected into animals becomes incorporated almost exclusively into deoxyribonucleic acid of cells preparing to divide and remains in their nuclei as a permanent label; the radioactivity is diluted to half with each cell division?. When the autoradiographic method is applied to tissues of animals killed serially, one can determine the time and place of origin of cells, their route and rate of migration, and their ultimate fate. 